\title{
Presidential Partisanship in Government Formation: \\ Do Presidents Favour Their Parties When They Appoint the \\ Prime Minister?
}

\author{
Cristina Bucur \\ Department of Political Science \\ University of Oslo \\ cristina.bucur@stv.uio.no \\ José Antonio Cheibub \\ Department of Political Science \\ Texas A\&M University \\ cheibub@tamu.edu
}




\begin{abstract}
Government formation in parliamentary democracies is supposed to occur within the parliament. Yet, outside actors, such as the head of state, may formally or informally influence which party holds the position of Prime Minister. The expansion in the number of countries combining parliamentarism and popularly elected presidents raised the concern that the latter, endowed with their own source of democratic legitimacy, would interfere in government formation in particularly egregious ways. This paper investigates whether presidents in parliamentary and semi-presidential democracies wield systematic influence on the PM party choice. Using data for 21 democracies since 1946, we show that they do, but only under very specific conditions: when they are popularly elected, when they are constitutionally allowed to select a prime minister designate and, fundamentally, when power in parliament is dispersed among a relatively large number of parties. Thus, certain presidents play a role in government formation only when multiple outcomes are more or less equally viable. For this reason, we argue, concerns about undue presidential interference in parliamentary democracies are unfounded.
\end{abstract}




\section{Introduction}

Parliamentarism is a political system in which the government needs to be supported, or at least tolerated, by a parliamentary majority in order to stay in office. For this reason, parliamentarism is considered to be a system that aligns the interests of the executive and legislative powers. In these systems, governments are said to emerge in parliament and government formation is supposed to be a process exclusively internal to parliament. Given the rules for government formation (Strøm et al. 1994), the factors that should determine which government is formed relate to attributes of political parties: the extent of their legislative base, their ideological position, and their expectations about future electoral performance.

Yet, how do heads of state fit into this view of parliamentary democracies? As actors external to parliaments, they should play no role in the government formation process. But heads of state in parliamentary democracies, even if conceived as being non-partisan and above politics, are often endowed with considerable institutional and political powers. For example, in some cases they set in motion the government formation process by designating who will first attempt to form a government; in other cases, they are politically strong due to the popular basis of their mandates. In fact, only in a handful of democracies do heads of state play no role in government formation. These are the remaining European monarchies, where exclusion from politics is the price kings and queens have paid for their continued existence as such. ${ }^{1}$ In all other parliamentary democracies, governments are formed in the shadow, so to speak, of an actor that may have institutional and political resources to wield considerable influence in forming a government. How influential is this actor? Does it significantly and systematically affect the outcome of the formation process? More specifically, to what extent can presidents can change the formation outcome that parliamentary parties would have otherwise reached?

To see the opportunities for and limitations of presidential influence in government formation, consider examples from Portugal and Romania. The aftermath 
of the 2015 parliamentary election in Portugal illustrates the limits of presidential involvement in government formation. Elections held on 4 October led to a situation in which no party alone held a majority of seats in parliament. The ruling Social Democratic Party (PSD) lost the parliamentary majority it had enjoyed since 2011 in coalition with the People's Party (PP), even though it remained the largest party in parliament. The second-placed Socialist Party (PS), in turn, announced the formation of a majority coalition with the Communist Party (PCP) and the Left Bloc (BE). President Cavaco Silva, a former Social-Democrat leader and prime minister, charged the incumbent PSD Prime Minister with the task of forming a new government. Although it was considered customary to ask the party holding the largest number of seats to form the government, never before had that party and its allies been in the minority and facing a majority opposition coalition. And although the constitution grants the president the power to unilaterally appoint the PM, it also requires the government formed by that PM to face a vote of investiture once in power, even if an institutionally easy one. ${ }^{2}$ President Cavaco Silva's decision was controversial, to say the least, nearly sparking what some saw as a constitutional crisis. ${ }^{3}$ When the time came, the centre-right minority government formed by Cavaco Silva's choice failed to survive the formal investiture vote. Faced with the reality of a unified majority opposition, the President, appointed as PM the Socialist Party's candidate, who proceeded to successfully win the vote of investiture in parliament.

The Portuguese episode illustrates a situation where parliamentary parties fully shaped government formation despite the president's attempt to use his constitutional powers to have a government led by his own party. Romania, in turn, illustrates a situation in which the President causes parties to realign in view of government formation. In the November 2004 concurrent presidential and legislative elections, the left-wing pre-electoral coalition formed by the Social-Democratic Party (PSD) and the much smaller Conservative Party (PC) topped the polls with $40 \%$ of the vote and started preparations to form a new government. Two weeks later, when the candidate endorsed by the centre-right Justice and Truth Alliance won the presidential 
runoff, things took a different turn. Even though the Justice and Truth Alliance had come second in the legislative election, newly-elected President Băsescu nominated a PM candidate from his supporting camp as he convinced the PC to break their preelection agreement with the PSD and join the new centre-right government. In this case the president successfully affected the formation outcome; but he did so by bringing the coalition he preferred to a majority status, and not by going against an existing majority.

The Portuguese and the Romanian examples illustrate two scenarios of presidential involvement in government formation. Under some circumstances, as the Portuguese episode shows, the president has little choice but to appoint the prime minister that parliamentary parties agree on. However, the president may be able to exercise some personal influence if general elections return a fragmented legislature or during times of political crisis. The Romanian example suggests that certain circumstances may allow presidents to get involved in coalition negotiations and change the government formation outcome that parliamentary parties would have otherwise reached. The question we raise in this paper is whether presidents are able to influence PM selection only exceptionally or if there is an independent and systematic effect of presidential partisanship on PM party choice.

The remainder of the paper is organised as follows. The next section reviews the literature on presidential influence on government formation in parliamentary and semi-presidential systems. We highlight the semi-presidential studies' focus on the link between directly elected presidents and nonpartisan appointments and the limited literature on the president's partisan influence in multiparty settings. The following section presents our dataset and empirical strategy to assess the role of presidents in government formation. We argue for the importance of distinguishing the partisan configurations underlying government formation. There are circumstances under which presidents would be simply unable to influence the formation process, even if he/she wanted or were constitutionally allowed to 
participate in it. We present our results in the final substantive section, which is followed by concluding remarks.

\section{The president's role in government formation: what do we know?}

With the expansion in the number of semi-presidential democracies since 1990, the presidents' influence on political outcomes has become the focus of a large literature. One of the key concerns was how an actor who serves a fixed term in office and who has an independent source of legitimacy - popular elections - would impact parliamentary decision-making. With respect to government formation, semipresidential constitutions blur the lines of government responsibility and accountability, as both presidents and assemblies may be involved in the appointment and dismissal of the executive (Shugart 2005). Thus, governments in semi-presidential systems are seen as agents who face two principals with distinct electoral mandates and strong claims to power (Protsyk 2006: 221; Schleiter and Morgan-Jones 2009: 668). Consequently, one of the key questions addressed by these studies was the extent to which "the strategic participation of the president in cabinet formation under semipresidentialism results in the appointment of cabinets that differ from those that would have been chosen if the 'ideal' presidential or parliamentary constitutional framework were in place" (Protsyk 2005: 722).

When it comes to government formation, the core issue in studies of semipresidentialism was not simply that presidents would somehow influence who would lead and be in the government. After all, heads of state in pure parliamentary systems and even constitutional monarchs have occasionally influenced government composition (Elgie 2015: 321-322). Instead, the issue was whether that influence would be exercised to produce significantly different outcomes as compared to the ones produced in other parliamentary systems. In the democratic monarchies, the head of state was, for all practical purposes, absolutely excluded from politics and government formation would proceed unencumbered by any non-parliamentary actor. In systems 
with a president elected by parliament, the head of state was expected to use whatever influence she had over government composition to facilitate parliamentary party government (Schleiter and Morgan-Jones 2009: 670). In other words, because both the president and the government emerged from parliamentary majorities, the presumption was that there would be a convergence of preferences among the different parts of the executive. In contrast, popular mandates were expected to provide presidents with incentives to "break" the chain of parliamentary delegation from assembly parties to the government by seeking non-partisan support (Amorim Neto and Strøm 2006). Consequently, non-partisan appointments to cabinet was thought to be one of the manifestations of presidential influence over government formation (Protsyk 2005; Amorim Neto and Strøm 2006; Schleiter and Morgan-Jones $2009,2010)$.

Presidential influence over the composition of parliamentary governments would also be manifest in the coincidence between the parties of the head of state and head of government. Although it is recognized that presidents can constrain coalition bargaining (Strøm et al. 1994), it is not a priori clear whether the way they came into office matters. On the one hand, indirectly elected presidents depend on their legislative party to obtain their mandate whereas directly elected presidents owe theirs to the electorate. For this reason, the former would have greater incentives than the latter to influence the choice of PM party to the benefit of their own organizations (Glasgow et al. 2011: 940). Reflecting this position, formal theorizing of government formation mostly assumed heads of state are nonstrategic in appointing a formateur (Diermeier and Merlo 2000; Bassi 2013) or have no preferences over potential governments (Morelli 1999; Bloch and Rottier 2002). On the other hand, precisely because their mandate originates 'with the people,' directly elected presidents could claim greater democratic legitimacy than indirectly elected presidents and thus be better positioned to freely influence the choice of PM party (Kang 2009: 550).

Regardless of how they were selected into office, presidents' influence over the choice of PM increases considerably if they possess powers of appointment. After 
all, in order to directly favour their party in the selection of the prime minster, presidents need to possess the formal powers to exercise such discretionary choices. Most European democracies involve the head of state in the nomination and/or formal appointment of the prime minister and her cabinet. However, it is not always the case, as Kang (2009: 547) assumes, that "at the first stage, the president is primarily a proposer who makes a take-it-or-leave-it offer to the parliament." There is significant variation in the role presidents play in this process, ranging from an active involvement in the full process of PM selection and cabinet appointment to merely formally appointing a PM that was nominated and selected exclusively by parliament (Laver and Schofield 1990: 208-210; Bäck and Dumont 2008: 354-355). Presidents who are constitutionally entitled to move first in nominating an individual as the head of government are in a better position to exercise personal influence in PM appointment. They have discretion in the sense that they are constitutionally free to choose whichever party they want to head a government. In contrast, presidents with a passive role in government formation have no opportunities for discretion in the process of government formation. Their formal participation is limited to appointing a head of government nominated and chosen by the parliament (like in Ireland and Germany), or to nominating a PM designated by the constitution (like in Bulgaria, where the president is required to nominate the leader of the largest party). When presidents have a proactive role in government formation, they can take advantage of their agenda-setting role to choose a PM who is closer to her preference than to the preferences of a majority (Romer and Rosenthal 1978). It is likely that a candidate from his own party would be preferable to a candidate from a different party. By contrast, when the role of the president is passive, the government formation process is more likely to follow the "free-style" bargaining principles predicted by most coalition theories (Laver and Schofield 1990: 208; Bäck and Dumont 2008: 355). Consequently, proactive presidents, regardless of how they were elected, might be better able to take advantage of bargaining opportunities to favour their party for the prime ministership. 
Additionally, the partisan configuration in the context of which governments are formed may significantly condition the power of presidents to influence the choice of PM party. All studies of coalition formation in parliamentary democracies naturally exclude majority situations, that is, cases in which one single party holds a majority of seats. In these cases, it is certain that the majority party will form the government and hold the premiership. Yet, even in minority situations, those in which no party holds a majority of seats, we can distinguish cases in which one party dominates the bargaining process and thus is almost certain to head the government, from those in which the outcome of the bargaining process is truly uncertain. It is only in the latter case, we argue, that the power of presidents to interfere in the parliamentary negotiations to form a government can be high and actually observed.

To see why, consider the only two published studies that specifically address the impact of heads of state in the choice of the party that will lead the government (Glasgow et al. 2011 and Kang 2009). Both studies find that the likelihood that the party of the president will also be the party of the PM is higher when the head of state is indirectly rather than directly elected. This is interpreted as evidence that indirectly elected presidents are relatively more successful in interfering in the government formation process in favour of their parties. Yet, a high correlation between the parties of the president and the PM when elections are indirect may result from two processes; but only one of these can be used as evidence that presidents independently influence the choice of PMs. In one case, the president chooses a co-partisan to head the government, even if their party is not the most likely to command the support of a parliamentary majority. In the other case, it just so happens that there is one party truly capable of commanding a legislative majority and, naturally, that party both elects the president and heads the government. Whereas in the former case the fact that the president and the PM belong to the same party reflects the power of the president, in the latter it does not. After all, the government that is formed is the same that would have been formed in the absence of the president. For this reason, failure to distinguish 
these two processes is likely to bias upward the estimate of the president's power in the choice of the party that will fill the PM office.

Thus, while the mode of selection of the head of state may matter for the choice of PM party, this effect is conditioned by both the constitutional power of any president to participate in the government formation process and the presence in parliament of parties whose government leadership is almost certain. To illustrate how these factors shape the president's active involvement in the selection of the prime minister, consider again the formation of the Romanian government after the 2004 concurrent presidential and legislative elections. Arguably, things would have played out differently if the constitution did not grant the head of state a proactive role in the nomination of the prime minister. However, the president's first-move advantage would have made little difference if the Social Democrats had won the general election by a greater margin. This is what happened after the 2012 general election, when President Băsescu had little choice but to appoint as PM the PSD leader. This time around, the pre-election coalition between PSD, PNL, and PC won the election with over $60 \%$ of the vote. Under these circumstances, the president was no longer able to use his unconstrained PM nomination power to alter the balance of forces established by the general election.

To sum up, we argue that to assess the role of presidents in parliamentary and semi-presidential systems in choosing the party that will head the government one needs to pay attention to the complexity of the bargaining environment and to the presidents' formal powers to sway negotiations over cabinet formation. Our expectation is that presidents, however they are elected, can actively favour their own parties for the prime ministership only if no clear-cut winner emerges from a general election and provided they can exploit a constitutionally proactive role in government formation. If this is the case, then it should be true that the lower the institutional constraints on the government formation process, for example by the absence of a strong investiture requirement, the more opportunities for the president's party to form the new government. 


\section{Data, measures, and method}

Our dataset consists of the government formations included in the ParlGov database (Döring and Manow 2015) and covers the 1945-2015 period. Caretaker and technocratic cabinets as well as governments formed in situations where a single party controlled the majority in parliament are excluded. Constitutional monarchies, where the preferences of monarchs over alternative PM parties cannot be estimated, are also excluded. Moreover, since we aim to estimate the extent to which presidents bias the PM selection process in favour of their own party, we also exclude government formations led by nonpartisan prime ministers and situations where presidents came to office as independent politicians. We use several sources to code the presidents' political affiliation, such as ParlGov and the "World Political Leaders" database (Zarate's Political Collections 2015). Presidents who contested elections as independents were coded as politically non-affiliated even if they were formally endorsed by one or more political parties. Our final dataset comprises 343 PM government formations and 2,985 potential PM parties in 21 countries. ${ }^{4}$

Several measures capture party-specific characteristics that have been consistently shown to impact the type of government that will be formed (Laver and Schofield 1990; Martin and Stevenson 2001, 2010; Bäck and Dumont 2008). We control for the percentage of legislative seats each party holds and use three dichotomous variables to capture information about whether the party that forms the government is the largest party in the legislature ${ }^{5}$, whether it is the party of the previous prime minister, and whether it is the median party. ${ }^{6}$

Additional indicators are employed to capture presidential characteristics. The first one designates the president's party. The second one indicates whether presidents play a proactive or passive role in the appointment of the prime minister. The coding of this variable is based on constitutional texts ${ }^{7}$. Proactive presidents are recorded if the constitution grants them the unconstrained power to nominate a prime minister. 
For example, this is the case in the Fifth French Republic, where the constitution simply mentions that "the president appoints the prime minister" (Article 8). Passive presidents are recorded when their participation is limited to appointing a head of government nominated and chosen by the parliament, or to nominating a premier designated by the constitution ${ }^{8}$.

The third presidential variable differentiates between heads of state who area chosen through direct and indirect elections. Table 1.1 classifies our cases based on the president's mode of election and their constitutional role in government formation. This classification shows that the president's role in government formation cuts across the mode of election. Thus, it is not the case that directly elected presidents are more likely to have a constitutionally defined active role in government formation than those who are indirectly elected. Table 1.2 indicates the distribution of government formations in our dataset according to the presidents' role in government formation and their mode of election.

[Tables 1.1-1.2]

As argued before, we consider how the political and partisan circumstances under which governments are formed affect the presidents' ability to use their position to benefit their own party. If one wishes to single out situations in which the head of state can exercise discretion, then one needs to focus on cases where large parties do not control legislative decision-making. The coalition formation literature has shown that political uncertainty and a fragmented party system affect the outcome of negotiations (Falcó-Gimeno and Indridason 2013). Moreover, Carroll and Cox (2012: 9) argue that fragmented party systems leave presidents "sufficiently unconstrained by norms mandating that they choose a large or the largest party" and more likely to "use their discretion to benefit their own party". Therefore, if presidents have partisan preferences in the selection of the prime minister and are constitutionally entitled to 
make the first proposal for a PM candidate, then they should be in a better position to tilt the balance in favour of their parties in more uncertain bargaining situations.

We incorporate uncertainty into our analysis by using Dumont and Grofman's (2015) classification of party systems, which is, in turn, based on Caullier and Dumont's (2010) index, the CDI:

$$
C D I=\frac{\sum_{i=1}^{n} B P I_{i}}{\max _{\mathrm{i} \in \mathrm{N}} B P I_{i}}
$$

where $\mathrm{BPI}_{i}$ is the Banzhaf (1965) power index of party $i$. CDI compares each party's voting power index with that of the largest party to determine how dominant it is relative to all other parliamentary parties. It takes the value of 1 whenever one party holds more than half of legislative seats. In these cases, the outcome of the bargaining process is determined: the majority party will head the government. As the largest party's share of seats becomes smaller than $50 \%$, its ability to dominate the bargaining process decreases and CDI increases. Thus, CDI increases as the complexity and uncertainty of the bargaining situation increases.

Dumont and Grofman (2015) propose collapsing the CDI index into four categories, which sufficiently describe the different scenarios under which parties must negotiate to form a government: when $\mathrm{CDI}$ is 1, bargaining is trivial as the largest party determines the outcome; when CDI is higher than 1 but lower than 2 , the largest party alone has more power than all other parties together; when CDI is higher than 2 but lower than 3, there is some balance between the largest party and some other party or parties; and when CDI is higher than 3 bargaining power is quite dispersed and the largest party is almost in parity with other party or parties. In our analysis, we discard the first category and separately consider the relationship between the parties of the president and prime minister for the other categories. We believe that a measure based on CDI is appropriate for our analysis because it combines the measurement of party system fragmentation and the identification of dominant parties (Caulier and Dumont 
2010: 45). In this sense, it provides more information about bargaining complexity and uncertainty than the widely used Laakso-Taagepera (1979) measure of the effective number of legislative parties (ENPP). ${ }^{9}$

Figure 1 shows the distribution of the 343 formation opportunities in our sample across the three relevant bargaining categories. A rug plot underneath the graph indicates the CDI values occurring in each of them sample. In almost one quarter of cases the largest party has more power than all other parties (CDI is higher than 1 but smaller than 2). It is unlikely that such a party would be excluded from the cabinet and almost certain that, given its participation in the government, it will hold the premiership. Under these circumstances, we expect party size alone to successfully predict the PM party. These are largely uninformative cases for studying the ability of presidents to influence government formation outcomes. The potential influence of the head of state increases as the fragmentation of the party system increases. In close to one third of formations the largest party is still powerful but there is more balance with respect to the second largest party. In the remaining $43 \%$ of the formation situations, bargaining power is more dispersed among two or more parties. We expect that in these two categories, the information on party size will be less efficient in predicting which party obtains the PM post. These are the cases in which presidential influence could be significant and where the presidential variables could have the greatest impact in predicting the party of the prime minister.

We model the choice of prime ministerial party as an unordered discrete choice problem, which treats every government formation opportunity as the unit of analysis and estimates the probability that each party out of the set of all legislative parties in a choice set obtains the PM post. The dependent variable in our analysis is coded 1 for the party that obtained the PM post, and 0 for all other parties. Since Martin and Stevenson (2001), the standard procedure for the empirical analysis of government formation outcomes has been McFadden's (1974) conditional logit (CL) model. A potential limitation of this model is that it assumes the independence of irrelevant alternatives (IIA). As a result, the model assumes that government formation 
situations are homogenous and is unable to deal with the unobserved heterogeneity generated by the variation in contextual factors across formation opportunities (Glasgow et al. 2012). The empirical tests we performed revealed that all the models presented in the results section violate the IIA assumption. ${ }^{10}$ As a result, we applied mixed effects logistic (MXL) regressions with random coefficients to model the choice of prime ministerial party. In contrast to the CL model, the MXL relaxes the IIA assumption and allows the effects of the independent variables to vary across PM selection opportunities (Glasgow et al. 2011: 941-942, 2012).

\section{Presidents, Power Dispersion, and PM Party Choice}

Before turning to our multivariate analysis, we first evaluate how many outcomes one can predict by guessing that the largest party will become the PM under different conditions of bargaining complexity. The first row in Table 2 indicates that, overall, one can predict which party obtains the PM post in $73 \%$ of the cases just by knowing the identity of the largest party. The next three rows distinguish levels of power fragmentation among legislative parties according to the categories defined in the previous section. We see that even in minority situations the largest party nearly always obtains the PM post when it clearly dominates the party system $(1<\mathrm{CDI}<2)$. Under a more balanced distribution of power between the largest and the other parties as a bloc $(2 \leq \mathrm{CDI}<3)$, the largest party obtains the prime ministership in $80 \%$ of the cases. When power is highly dispersed (CDI $\geq 3$ ), the identity of the largest party correctly predicts only $53 \%$ of the outcomes. Given the lack of variation that can be explained by other factors than party size in the category of low power dispersion, we consider the relationship between presidents and PM parties in situations of medium and high power dispersion.

[Table 2] 
We estimate five mixed logit models to evaluate the extent to which the selection mode and constitutional powers of the head of state affect the choice of PM party. The MXL model can contain both fixed and random coefficients. To determine which variables should have a random coefficient, we used the Lagrange multiplierequivalent tests suggested by Glasgow et al. (2012: 255). ${ }^{11}$ The models presented in Tables 3 and 4 exhibit some variation in the designation of fixed and random coefficients, depending on the variables included in each MXL specification. In line with previous studies (Bäck and Dumont 2008; Kang 2009), we evaluate the predictive efficiency of our models by, first, generating for each party the probability that it will head the government and, second, stipulating that the party with the highest probability is the one that will obtain the PM post. Prediction rates are computed as the proportion of cases that are correctly predicted by each of the models presented. We are interested in both the statistical significance of the president-related variables and in how much these variables improve our ability to predict which party succeeds in forming the government (Ward et al. 2010).

In both tables we start with a baseline model of PM party choice, which includes three standard measures related to parliamentary parties' attributes: an indicator for the largest party in the legislature (keeping in mind that it cannot be larger than $50 \%$ since we exclude all majority situations), an indicator for the party of the previous prime minister (incumbency status), and an indicator for the median party. Model 2 adds an indicator for the president's party and Models 3-5 examine whether the president's mode of election and the president's power to nominate a candidate for PM modify the impact of being the party of the president. As we explained above, directly elected presidents are not guaranteed the support of a legislative majority and have an incentive to interfere on the government formation process in a way that parliament-elected presidents do not have (Model 3). At the same time, presidents who are constitutionally allowed to nominate a candidate for PM, compared to those who cannot, are able to directly shape the formation of governments (Model 4). Given that one variable affects the president's incentive to 
interfere and the other the president's ability to do so, presidents who are directly elected and constitutionally allowed to nominate the candidate for PM should be better positioned to have a co-partisan at the government helm (model 5). We examine each of these possibilities by interacting the indicator of presidential party with two dichotomous variables corresponding to each president-specific attribute (mode of election and constitutional power). Note that in these interactions, at least one of the terms is constant for each formation opportunity, meaning that, given a formation opportunity, it has no impact whatsoever on the choice of PM party. Since this means that there is nothing to be estimated with respect to these variables, the interactive models in tables 3 and 4 do not contain all the interactions' constitutive terms. ${ }^{12}$

Under conditions of moderate bargaining complexity (Table 3), all that matters are the intra-parliament factors that existing theory suggests should differentiate parties and give them some degree of bargaining advantage: being the largest party in parliament, the party that occupies the median position in the legislature, and the party of the previous prime minister. These variables do not increase our ability to correctly predict the party of the PM (compare the row labelled 'Prediction Rate' in Table 3 with the third row in Table 2), but the coefficients for the three variables are positive and statistically different from zero. Being the party of the president, regardless of her mode of election or her nominating powers, has no effect on the choice of PM party. As a matter of fact, likelihood ratio tests comparing Model $2-5$ with the baseline model, reported at the bottom of Table 3, confirm that presidential variables do not increase the models' predictive efficiency. Therefore, we can confidently conclude that in situations of moderate power fragmentation one has an $80 \%$ chance of correctly predicting the party of the prime minister by simply knowing whether it is the largest legislative party.

[Table 3] 
Things are quite different when the bargaining environment within the legislature is more complex and multiple alternatives are viable to head a government (Table 4). The intra-parliamentary variables continue to matter, and together they improve, even if not dramatically, our ability to predict which party will hold the premiership: the rate of correct predictions go from $55 \%$ when all we know is who is the largest party (fourth row in Table 2), to $64 \%$ when we add information about the party's relative position and incumbency status. In fact, information about the party of the president and the president's mode of election and constitutional power does not add any predictive power to this baseline model. That said, the results shown in Models 1 indicate the presence of unobserved heterogeneity surrounding the effect of being the party of the previous prime minister. The fact that the mean coefficient on Previous PM is 1.82 with a statistically significant standard deviation of 1.82 means that $86 \%$ of the distribution of estimated coefficients is above zero (the PM party is advantaged) and 16\% is below zero (the PM party is disadvantaged).

[Table 4]

As to the party of the president, although it is still not statistically significant (Model 2), the standard deviation of the coefficients also suggests heterogeneity. The party of the president may matter under some conditions but not others. As previously discussed, we consider two such conditions: the mode of election and the president's power to set in motion the formation process.

Once we consider the mode of election, we find that parties of popularly elected presidents are not more likely to provide the PM, although here too heterogeneity seems to be present. But when presidents are chosen by parliaments, the correlation between their party and that of the PM is positive and statistically significant. This is consistent with the findings reported by Kang (2009) and Glasgow et al. (2011). However, as we discussed above, this does not necessarily reflect the president's ability to influence from which party the PM will be chosen. Rather, we 
believe it simply reflects the fact that the majority that forms a government also chooses the president. We need, therefore, to further investigate this effect.

Model 5 in table 4 combines the two presidential attributes by interacting them with the indicator for the presidential party. This provides estimated coefficients for the four configurations in Table 1. The baseline against which the coefficients must be evaluated are formation opportunities with identical attributes (e.g., directly elected president with nominating powers) but for non-presidential parties. Thus, as we can see, we find that when presidents are directly elected and are allowed to nominate a PM candidate, presidential parties, as compared to non-presidential parties, are more likely to end up holding the premiership. In substantive terms, the exponential transformation of the coefficient corresponding to this variable suggests a six-fold increase in the odds ratio of being the PM party for presidential parties as compared to non-presidential parties. The caveat about the odds ratio, however, is that it assumes IIA, an assumption relaxed by the mixed logit model. Nevertheless, the fact that the Lagrange multiplier test did not indicate the need to include a random coefficient for this variable suggests the absence of heterogeneity across formation opportunities. This result survives even if we remove from the sample countries, such as Austria and Finland, which contribute a relatively large number of formation opportunities.

We also find that when presidents are chosen by the parliament and have no power to nominate a PM candidate, their parties are also more likely to hold the premiership. This effect, however, is spurious in the sense suggested above: they simply reflect the coincidence between the parties of the two leaders, rather than the agency of one of these leaders in the choice of the other. That is to say, parliamentary rules for the election of the president and for the choice of PM allows one party to forge majorities and capture both posts. We are buttressed in this interpretation by the fact that a large number of observations in this category comes from two countries where we can be reasonably sure, if not certain, that the fact that a member of the same party occupies the presidency and the premiership did not result from the strategic behavior of the former: Germany and Israel. Once we remove one or both from the sample, the 
coefficient for the category of "parties of presidents who are chosen by parliament and play no role in the formation process" becomes smaller and loses statistical significance.

All in all, we must also note that the final model's predictive efficiency rate does not increase substantially with regard to the baseline model or to a model that only includes a simple indicator for the president's party. In other words, taken as a whole, president-specific characteristics make a modest contribution to predictive power. Nevertheless, according to the log-likelihood tests that compare Models 2-5 with the baseline Model 1 in Table 4, we can safely reject the null hypothesis that the presidential variables have no significant effect on the PM party choice outcome.

We tested the robustness of these results in several ways. First, we applied conditional logit models to our data and found no substantive differences in the magnitude and significance of coefficients. These results are provided in Tables A1 A2 in the Appendix. Second, we extended the dataset to include cabinets with nonpartisan prime ministers and parliamentary systems with monarchs as heads of state. These extensions are not theoretically appropriate since it includes cases for which the partisanship of the head of state or of the government is unavailable. But since results based on samples that included these cases have been reported, we wanted to make sure that any differences were not due to the composition of the samples. They are not, as Tables C3 and C5 in the Appendix demonstrate. We also investigated whether restricting the sample to post-1990 government formations, when many Eastern European countries entered the sample, would change anything. Tables B1-B4 in the Appendix present the distribution of our data across different time periods and regions. Tables C4 and C6 in the Appendix present the estimations limited to post1990 government formations. Overall, these results do not differ a great deal from the ones we obtain from the main sample. That said, a slight increase in the explanatory power of presidential variables can be noticed, especially under conditions of high power dispersion (Table C6).

To sum up, we find that party size, incumbency, and median position are the most important predictors of PM party choice and are consistently estimated to have 
a positive impact on that choice. However, as power dispersion increases, so does the uncertainty about which party will end up heading the government. It is under these circumstances of high uncertainty that we found evidence of presidential influence on government formation outcomes. In these cases, presidents are electorally motivated and the stakes from having a government headed by a co-partisan may be high. Additionally, they are granted the constitutional power to act in the formation process at a moment that may confer strategic advantage. However, this only happens when government formation occurs in an uncertain environment, in which no party holds a clear numerical advantage over all other parties. Therefore, the costs of presidential influence are relatively low. To the extent that they are willing and capable to act in the interest of their own party, they do so only when there are multiple viable outcomes. When there is an identifiable winner of the formation process, even presidents who have their independent political base and formal nominating powers must go along with the 'normal' course of things and accept a government that may not be of his or her liking.

\section{Conclusion}

Part of the motivation for asking the question we address in this paper is normative. It comes from a concern that an external actor - the president - will influence a process that should be strictly internal to the parliament. Presidents, even if elected by parliament, are external actors since they are conceived as part of the executive and, once elected, are not responsible to parliament. By making presidential elections direct, semi-presidential constitutions potentially complicate the nature of government formation.

Previous studies have found that only presidents selected by parliament were able to influence the choice of PM. This finding, on the one hand, help reduce concerns with external 'interference' in the government formation process: if presidential interference is a reality, at least it only happens when presidents emerge from within 
parliament. But on the other hand, it raises the spectre of non-aligned parts of the executive, including the possibility of 'cohabitation', the delicate situation in which the president and the prime minister come from different and politically opposed parties.

Our findings suggest a different story. We set out to determine whether presidents are systematically able to act as partisan actors in PM selection. Our approach focused on the different partisan configurations under which governments are formed, on the constitutional powers that presidents can use to pursue their partisan goals, and on the way presidents come to office. We argued that to evaluate properly the role of the president in government formation we need to separate situations in which the outcome is essentially determined by the partisan distribution of parliamentary seats from those in which it is indeterminate. It is in the latter that the potential for presidential interference in government formation should be high and observable.

We distinguished conditions of bargaining uncertainty on the basis of a measure that considers both the fragmentation of parliament and the power of the largest party relative to the other parties. We found that whenever the distribution of power in parliament clearly favours one party, the head of the government is typically occupied by the largest legislative party. Under conditions of high bargaining uncertainty, however, we found that indirectly elected presidents, regardless of their constitutional powers, do not directly act to favour their party in the choice of prime minister. Whatever correlation may exist between the parties of the two leaders, it is produced by the fact that the same majority that captures one post also captures the other. But under the same bargaining conditions, directly elected presidents who are constitutionally enabled to participate in the formation process do act to increase the chance that a co-partisan will become prime minister.

Does this constitute undue presidential intervention in the formation of governments? We believe it does not. Presidential 'interference' occurs only when power is sufficiently dispersed inside parliament and more than one governing coalition is viable. Granted the constitutional opportunity to make a choice, presidents 
do it in a way that will increase the chances that a co-partisan will be at the head of the government. Given the power fragmentation in parliament, it may not be necessarily detrimental to the functioning of the government to be formed that the president and the prime minister belong to the same party.

The broad message that our findings convey, however, is that government formation, even if subject to the potential intervention of presidents, is essentially determined within parliament. What matters the most, even when power is fragmented and thus uncertainty high, is the claim to government leadership that relatively large parties can make, the parties' location with respect to the chamber's preferences, and the ability of the previous prime minster to manoeuvre if not for her continuation in power, at least for the continuation of her own party. Some presidents may be able to interfere, but such interference may actually be positive from the point of view of governance. 


\section{Tables and Figures}

Table 1.1 Heads of state in European countries: role in government formation and mode of election (1945-2015)

\section{President's role in government formation}

\begin{tabular}{|c|c|c|c|}
\hline & & Proactive & Reactive \\
\hline & & Austria (1951-2014) & Bulgaria (1992-2014) \\
\hline & & Czechia (2013-2014) & Croatia (2000-2014) \\
\hline & & France (1965-2014) & Finland (2000-2014) \\
\hline & & Iceland (1945-2014) & Ireland (1945-2014) \\
\hline & Direct & Finland (1945-1999) & Poland (1993-2014) \\
\hline & & Poland (1991-1992) & Slovenia (1992-2014) \\
\hline & & Portugal (1976-2014) & \\
\hline & & Romania (1991-2014) & \\
\hline $\begin{array}{c}\text { Mode of } \\
\text { precidential }\end{array}$ & & Slovakia (1999-2014) & \\
\hline election & & Turkey (2014) & \\
\hline & & Austria (1945-1950) & Bulgaria (1991) \\
\hline & & Czechia (1993-2012) & Estonia (1992-2014) \\
\hline & & France (1946-1964) & Germany (1949-2014) \\
\hline & & Hungary (1991-2014) & Greece (1975-2014) \\
\hline & Indirect & Italy (1948-2014) & Israel (1968-2014) \\
\hline & 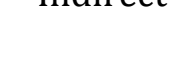 & Israel (1949-1967) & \\
\hline & & Latvia (1993-2014) & \\
\hline & & Poland (1989) & \\
\hline & & Slovakia (1993-1998) & \\
\hline & & Turkey (1983-2013) & \\
\hline
\end{tabular}

Table 1.2 Presidents and government formations

President's role in government formation

\begin{tabular}{lccc}
\hline & & Proactive & Reactive \\
\cline { 3 - 4 } $\begin{array}{c}\text { Mode of } \\
\text { presidential } \\
\text { election }\end{array}$ & Direct & 101 & 52 \\
\cline { 2 - 4 } & Indirect & 104 & 86 \\
\hline
\end{tabular}


Table 2. Largest party predictor of PM party at varying cut-points of bargaining complexity

\begin{tabular}{cccc}
\hline $\begin{array}{c}\text { Party system } \\
\text { domination (CD-Index) }\end{array}$ & $\begin{array}{c}\text { Formation } \\
\text { Opportunities }\end{array}$ & $\begin{array}{c}\text { PM = Largest Party } \\
(\#)\end{array}$ & $\begin{array}{c}\text { PM = Largest Party } \\
\text { (\%) }\end{array}$ \\
\hline All & 348 & 254 & $73 \%$ \\
$(1,2)$ & 83 & 82 & $99 \%$ \\
{$[2,3)$} & 114 & 91 & $80 \%$ \\
$\geq 3$ & 146 & 81 & $55 \%$
\end{tabular}


Table 3. Mixed logit analysis of PM party choice in moderately-fragmented party systems $(2 \geq \mathrm{CDI}<3)$

\begin{tabular}{|c|c|c|c|c|c|c|c|c|c|c|}
\hline & \multicolumn{10}{|c|}{ Dependent Variable: Prime Ministerial Party $(1,0)$} \\
\hline & \multicolumn{2}{|c|}{ Model 1} & \multicolumn{2}{|c|}{ Model 2} & \multicolumn{2}{|c|}{ Model 3} & \multicolumn{2}{|c|}{ Model 4} & \multicolumn{2}{|c|}{ Model 5} \\
\hline & Mean & SD & Mean & SD & Mean & SD & Mean & SD & Mean & SD \\
\hline \multicolumn{11}{|l|}{ Party Characteristics } \\
\hline \multirow[t]{2}{*}{ Largest party } & $3.29 * * *$ & & $3.26^{* * *}$ & & $3.26^{* * *}$ & & $3.25^{* * *}$ & & $3.27^{* * *}$ & \\
\hline & $(0.44)$ & & $(0.45)$ & & $(0.45)$ & & $(0.44)$ & & $(0.45)$ & \\
\hline \multirow[t]{2}{*}{ Previous PM } & $1.31^{* *}$ & $2.07^{* * *}$ & $1.25^{* * *}$ & $2.11^{* * *}$ & $1.26^{* * *}$ & $2.15^{* * *}$ & $1.25^{* * *}$ & $2.01^{* *}$ & $1.28^{* * *}$ & $2.09^{* *}$ \\
\hline & $(0.44)$ & $(0.78)$ & $(0.45)$ & $(0.79)$ & $(0.46)$ & $(0.80)$ & $(0.44)$ & $(0.78)$ & $(0.45)$ & $(0.81)$ \\
\hline \multirow[t]{2}{*}{ Median party } & $0.79 *$ & & $0.75^{*}$ & & $0.75^{*}$ & & $0.75^{*}$ & & $0.75^{*}$ & \\
\hline & $(0.41)$ & & $(0.42)$ & & $(0.42)$ & & $(0.41)$ & & $(0.42)$ & \\
\hline \multirow[t]{2}{*}{ President party } & & & 0.25 & & & & & & & \\
\hline & & & $(0.46)$ & & & & & & & \\
\hline \multicolumn{11}{|l|}{ Election Modes } \\
\hline \multirow[t]{2}{*}{ PR party $\times$ Direct election } & & & & & -0.03 & & & & & \\
\hline & & & & & $(0.62)$ & & & & & \\
\hline \multirow[t]{2}{*}{$\begin{array}{l}\text { PR party } \times \text { Indirect } \\
\text { election }\end{array}$} & & & & & 0.54 & & & & & \\
\hline & & & & & $(0.62)$ & $(1.37)$ & & & & \\
\hline \multicolumn{11}{|l|}{ Constitutional Roles } \\
\hline \multirow[t]{2}{*}{ PR party $\times$ Proactive role } & & & & & & & 0.41 & & & \\
\hline & & & & & & & $(0.54)$ & & & \\
\hline \multirow[t]{2}{*}{ PR party $\times$ Reactive role } & & & & & & & -0.05 & & & \\
\hline & & & & & & & $(0.71)$ & & & \\
\hline \multicolumn{11}{|l|}{ Presidential Scenarios } \\
\hline \multirow[t]{2}{*}{$\begin{array}{l}\text { PR party } \times \text { Direct election } \\
\times \text { Proactive role }\end{array}$} & & & & & & & & & 0.35 & \\
\hline & & & & & & & & & $(0.73)$ & \\
\hline \multirow[t]{2}{*}{$\begin{array}{l}\text { PR party } \times \text { Direct election } \\
\times \text { Reactive role }\end{array}$} & & & & & & & & & -0.76 & \\
\hline & & & & & & & & & $(1.00)$ & \\
\hline \multirow[t]{2}{*}{$\begin{array}{l}\text { PR party } \times \text { Indirect } \\
\text { election } \times \text { Proactive role }\end{array}$} & & & & & & & & & 0.48 & 0.02 \\
\hline & & & & & & & & & $(0.77)$ & $(0.96)$ \\
\hline \multirow[t]{2}{*}{$\begin{array}{l}\text { PR party } \times \text { Indirect } \\
\text { election } \times \text { Reactive role }\end{array}$} & & & & & & & & & 0.55 & \\
\hline & & & & & & & & & $(0.98)$ & \\
\hline N-Formations & \multicolumn{2}{|c|}{114} & \multicolumn{2}{|c|}{114} & \multicolumn{2}{|c|}{114} & & & & \\
\hline N-Parties & & & & 43 & & 3 & & & & \\
\hline Log-likelihood & & 64 & & .49 & & 25 & & & & \\
\hline Prediction rate & & & & 8 & & 8 & & & & \\
\hline Outcomes predicted & & & & 1 & & 1 & & & & \\
\hline LR $\chi 2$ vs. Model 1 & & & & 31 & & 78 & & & & \\
\hline
\end{tabular}

Note: Results are from a mixed logit model. Standard errors in parentheses (clustered by government). For each model, the "Mean" column indicates the fixed coefficients and the means of the random coefficients and the "SD" column indicates the standard deviation of the random coefficients. The LR $\chi 2$ tests compare Models 2-5 to the baseline Model $1 .^{*} \mathrm{p}<0.10,{ }^{* *} \mathrm{p}<0.05,{ }^{* * *} \mathrm{p}<0.01$. 
Table 4. Mixed logit analysis of PM party choice in highly-fragmented party systems (CDI $\geq 3$ )

\begin{tabular}{|c|c|c|c|c|c|c|c|c|c|c|}
\hline & \multicolumn{10}{|c|}{ Dependent Variable: Prime Ministerial Party $(1,0)$} \\
\hline & Mean & SD & Mean & SD & Mean & SD & Mean & SD & Mean & SD \\
\hline \multicolumn{11}{|l|}{ Party Characteristics } \\
\hline \multirow[t]{2}{*}{ Largest party } & $2.02^{* * *}$ & & $1.95^{* * *}$ & & $1.97^{* * *}$ & & $1.89^{* * *}$ & -0.17 & $2.05^{* * *}$ & -0.08 \\
\hline & $(0.28)$ & & $(0.30)$ & & $(0.30)$ & & $(0.28)$ & $(1.08)$ & $(0.30)$ & $(0.86)$ \\
\hline Previous PM & $(0.31)$ & $(0.74)$ & $(0.34)$ & $(0.34)$ & $(0.32)$ & & $(0.29)$ & $(0.90)$ & $(0.36)$ & $(0.95)$ \\
\hline \multirow[t]{2}{*}{ Median party } & $1.34^{* * *}$ & & $1.35^{* * *}$ & & $1.37^{* * *}$ & & $1.26^{* * *}$ & & $1.48^{* * *}$ & \\
\hline & $(0.28)$ & & $(0.31)$ & & $(0.29)$ & & $(0.27)$ & & $(0.31)$ & \\
\hline President party & & & 0.64 & $2.03^{* *}$ & & & & & & \\
\hline \multirow[t]{2}{*}{ PR party $\times$ Direct election } & & & & & 0.86 & $2.65^{* *}$ & & & & \\
\hline & & & & & $(0.60)$ & $(1.07)$ & & & & \\
\hline \multirow[t]{2}{*}{$\begin{array}{l}\text { PR party } \times \text { Indirect } \\
\text { election }\end{array}$} & & & & & $0.69 *$ & & & & & \\
\hline & & & & & $(0.36)$ & & & & & \\
\hline \multicolumn{11}{|l|}{ Constitutional Roles } \\
\hline \multirow[t]{2}{*}{ PR party $\times$ Proactive role } & & & & & & & $1.08^{* * *}$ & & & \\
\hline & & & & & & & $(0.33)$ & & & \\
\hline PR party $\times$ Reactive role & & & & & & & 0.5 & 1.77 & & \\
\hline \multicolumn{11}{|l|}{ Presidential Scenarios } \\
\hline $\begin{array}{l}\text { PR party } \times \text { Direct election } \\
\times \text { Reactive role }\end{array}$ & & & & & & & & & $(1.89)$ & $(2.85)$ \\
\hline \multirow[t]{2}{*}{$\begin{array}{l}\text { PR party } \times \text { Indirect } \\
\text { election } \times \text { Proactive role }\end{array}$} & & & & & & & & & 0.02 & \\
\hline & & & & & & & & & $(0.65)$ & \\
\hline \multirow{2}{*}{$\begin{array}{l}\text { PR party } \times \text { Indirect } \\
\text { election } \times \text { Reactive role }\end{array}$} & & & & & & & & & $1.32^{* *}$ & \\
\hline & & & & & & & & & $(0.59)$ & \\
\hline N-Formations & \multicolumn{2}{|c|}{146} & \multicolumn{2}{|c|}{146} & \multicolumn{2}{|c|}{146} & & & & \\
\hline N-Parties & & & & & & & & & & \\
\hline Log-likelihood & -17 & .27 & & 68 & -16 & & -16 & 39 & & \\
\hline Prediction rate & & & & & & & & & & \\
\hline Outcomes predicted & & & & & & & & & & \\
\hline LR $\chi 2$ vs. Model 1 & & & & $3^{* * *}$ & 17. & $* * *$ & 13.7 & $; * * *$ & & $* * *$ \\
\hline
\end{tabular}

Note: Results are from a mixed logit model. Standard errors in parentheses (clustered by government). For each model, the "Mean" column indicates the fixed coefficients and the means of the random coefficients and the "SD" column indicates the standard deviation of the random coefficients. The LR $\chi 2$ tests compare Models 2-5 to the baseline Model $1 .{ }^{*} \mathrm{p}<0.10,{ }^{* *} \mathrm{p}<0.05,{ }^{* * *} \mathrm{p}<0.01$. 
Figure 1. Power dispersion across formation situations

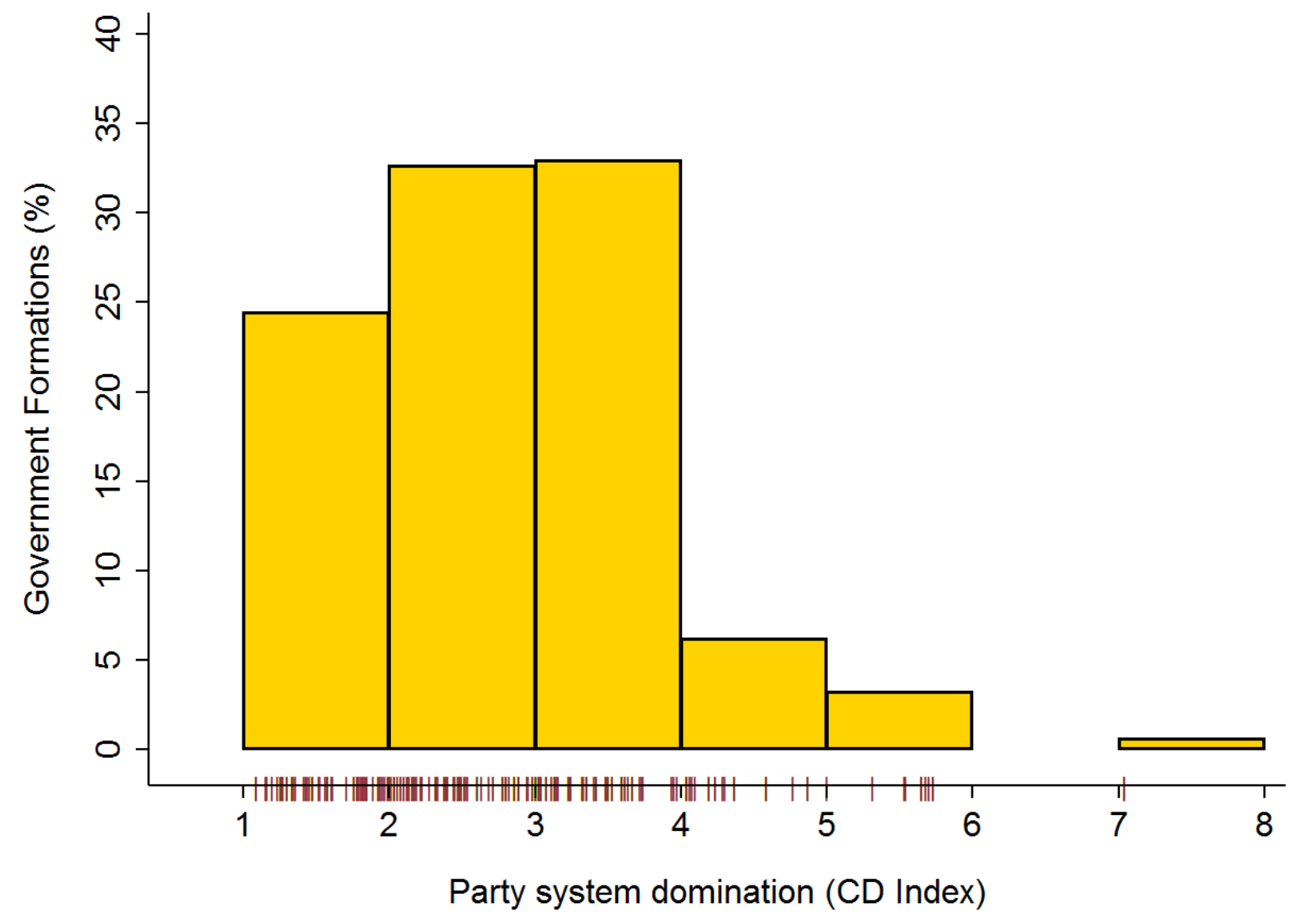




\section{Notes}

${ }^{1}$ The transformation of traditional monarchies into democracies occurred over a relatively long period of time in countries such as the United Kingdom, Belgium, Luxembourg, Denmark, Norway, Sweden and the Netherlands. But only in the last three, and recently, have monarchs been formally completely excluded from the government formation process.

${ }^{2}$ Investiture in Portugal is said to be relatively easy because the decision rule is a 'negative majority.' This means that the government facing the investiture vote will stay in power unless an absolute majority of the chamber votes against it. See Rasch, Martin and Cheibub (2015) for a discussion of investiture procedures, and LestonBandeira and Fernandes (2015) for a discussion of investiture in Portugal.

${ }^{3}$ See for example reactions in the British The Telegraph:

(http://www.telegraph.co.uk/finance/economics/11949701/AEP-Eurozone-crosses-

Rubicon-as-Portugals-anti-euro-Left-banned-from-power.html).

${ }^{4}$ The countries, time periods, and number of government formations included in the main sample are provided in the Appendix (Table A1).

${ }^{5}$ We experimented with alternative measures to capture legislative size, ideological policy proximity, and bargaining power. First, we estimated a party's probability of leading a majority coalition considering only arithmetical constraints. For each formation opportunity, we calculated the probability that a party will lead a majority coalition (the number of majority coalitions in which it is the largest party divided by the number of majority coalitions). Second, we took into account both arithmetical constraints and ideological proximity by using an algorithm based on Grofman's (1982) model of protocoalition formation. Third, we placed a tentative ban on the formation of protocoalitions with extremist parties. Finally, we computed voting weights and Banzhaf power index scores. None of these measures performed significantly better than the largest party indicator. This analysis can be obtained from the authors. 
${ }^{6}$ Most of the data for the median party variable comes from the European Representative Democracy Data Archive (Andersson et al. 2014). For the cases where this data is missing, we used the party positions data on the left-right dimension from ParlGov to determine the party closest to the median voter ideology employing the procedure outlined by Kim and Fording (1998: 98-99).

7 The data for the classification of proactive and passive presidents has been coded from the constitutional documents included in HeinOnline's World Constitutions Illustrated.

8 Since we are primarily interested in the role presidents play in the appointment of the prime minister, existing measures of presidential are not appropriate. For example, although Shugart and Carey's (1992) and Metcalf's (2000) indices of presidential powers account for the president's role in government formation, the appointment of the prime minister is just one of the powers measured on the 0 to 4 scale. Thus, even presidents with discretionary powers in the selection of the prime minister, such as the French president, do not usually score above 1 on this scale. Additionally, both indices are limited to popularly elected presidents. We also considered using data from Siaroff's (2003) index of presidential powers, which includes a dichotomous indicator for discretionary appointment powers (AP) and another one for the president's role in government formation (GF). However, neither of these indicators captures information uniquely related to the president's PM appointment powers. Previous works also found that the two indicators capture different dimensions of presidential powers (Elgie et al. 2014: 471).

${ }^{9}$ The correlation between ENPP and CDI is 0.76 and highly significant across all governments in our dataset, excluding the caretaker ones. If we exclude situations where a single party has a majority of seats, the correlation drops to 0.69 . If we also exclude constitutional monarchies, the correlation goes down to 0.67 . For cases of high power dispersion, when the CDI is higher than 3, the correlation with ENPP is 0.71. This suggests that while both measures can be used as indicators of party system fragmentation, CDI, as we would expect, captures something that ENPP does not. 
${ }^{10}$ We performed the IIA tests following Martin and Stevenson's (2001: 39) HausmanMcFadden (HM) test. The program performing this procedure is available online at http://www.randystevenson.com/research/. The average p-value we obtained from the sets of HM tests (we recalculated this statistic fifty times for each model) was above 0.10, indicating that the IIA assumption was not violated at global level. However, a number of individual HM tests were highly significant for each model, providing evidence of at least one IIA violation (Glasgow et al. 2012: 252). The results of these tests are provided in Tables A1-A2 in the Appendix.

${ }^{11}$ Following Glasgow et al. (2012: 255) and McFadden and Train (2000) we ran conditional logit models that included artificial variables for each independent variable. We evaluated which of the 'artificial' variables added to the model's explanatory power and used a t-value of ' 1 ' as the threshold for entering any of the variables into the models as random effects.

12 Note that it is not necessary to include the presidential party indicator in the model together with the interaction terms. Given that the indicators for direct and indirect election are mutually exclusive, for each case where the presidential party indicator is one, only one interaction term will be nonzero. The lack of the constant term in the mixed logit specification allows us to use multiplicative variables without causing an identification problem (Kang 2009: 569). 


\section{References}

Amorim Neto, Octavio, and Kaare Strøm (2006). "Breaking the Parliamentary Chain of Delegation: Presidents and Non-partisan Cabinet Members in European Democracies", British Journal of Political Science, 36:04, 619-43.

Andersson, Staffan, Torbjörn Bergman, and Svante Ersson (2014). The European Representative Democracy Data Archive, Release 3. Main sponsor: Riksbankens Jubileumsfond (In2007-0149:1-E). [www.erdda.se].".

Bäck, Hanna, and Patrick Dumont (2008). "Making the first move: A two-stage analysis of the role of formateurs in parliamentary government formation", Public Choice, 135, 353-73.

Bassi, Anna (2013). "A Model of Endogenous Government Formation", American Journal of Political Science, 57:4, 777-93.

Bloch, Francis, and Stéphane Rottier (2002). "Agenda control in coalition formation", Social Choice and Welfare, 19:4, 769-88.

Carroll, Royce, and Gary W. Cox (2012). Presidents and their Formateurs. Available at SSRN: http://ssrn.com/abstract=1905305.

Caulier, Jean-François, and Patrick Dumont (2010). "Measuring one-party dominance with voting power indices", in Matthijs Bogaards and Francoise Boucek (eds.), Dominant Political Parties and Democracy. Concepts, measures, cases, and comparisons. London, New York: Routledge, 45-59.

Diermeier, Daniel, and Antonio Merlo (2000). "Government Turnover in Parliamentary Democracies", Journal of Economic Theory, 94, 46-79.

Döring, Holger, and Philip Manow (2015). Parliaments and governments database (ParlGov): Information on parties, elections and cabinets in modern democracies. Development version.

Elgie, Robert (2015). "Heads of state in European politics", in José M. Magone (ed.), Routledge Handbook orf European Politics. London, New York: Routledge, 311-27.

Elgie, Robert, Cristina Bucur, Bernard Dolez, and Annie Laurent Laurent (2014).

"Proximity, Candidates, and Presidential Power: How Directly Elected Presidents Shape the Legislative Party System.", Political Research Quarterly, 67:3, 467-77.

Falcó-Gimeno, Albert, and Indridi H. Indridason (2013). "Uncertainty, Complexity, and Gamson's Law: Comparing Coalition Formation in Western Europe", West European Politics, 36:1, 221-47.

Glasgow, Garrett, Matt Golder, and Sona N. Golder (2011). "Who 'Wins'?

Determining the Party of the Prime Minister", American Journal of Political Science, 55:4, 937-54.

Glasgow, Garrett, Matt Golder, and Sona N. Golder (2012). "New empirical strategies for the study of parliamentary government formation", Political Analysis, 20:2, 248-70.

Grofman, Bernard (1982). "A Dynamic Model of Protocoalition Formation in Ideological N-Space", Behavioral Science, 27:1, 77-90. 
Kang, Shin-Goo (2009). "The influence of presidential heads of state on government formation in European democracies: Empirical evidence", European Journal of Political Research, 48:4, 543-72.

Kim, Hee Min, and Richard C Fording (1998). "Voter ideology in western democracies, 1946-1989", European Journal of Political Research, 33:1, 73-97.

Laakso, M., and Rein Taagepera (1979). "Effective' Number of Parties: A Measure with Application to West Europe", Comparative Political Studies, 12:1, 3-27.

Laver, Michael, and Norman Schofield (1990). Multiparty Government. The Politics of Coalition in Europe. Ann Arbor: University of Michigan Press.

Leston-Bandeira, Cristina, and Jorge M. Fernandes (2015). "Parliamentary Investiture Rules in Portugal's Semi-Presidential Democracy", in Bjørn Erik Rasch, Shane Martin, and José Antonio Cheibub (eds.), Parliaments and Government Formation. Unpacking Investiture Rules. Oxford: Oxford University Press, 217-32.

Martin, Lanny W., and Randolph T. Stevenson (2001). "Government Formation Parliamentary Democracies", American Journal of Political Science, 45:1, 33-50.

Martin, Lanny W., and Randolph T. Stevenson (2010). "The Conditional Impact of Incumbency on Government Formation", American Political Science Review, 104:03, 503-18.

McFadden, Daniel (1974). "Conditional Logit Analysis of Qualitative Choice Behavior", in P. Zarembka (ed.), Frontiers in Econometrics. New York: Academic Press, 105-42.

McFadden, Daniel, and Kenneth Train (2000). "Mixed MNL models for discrete response", Journal of Applied Econometrics, 15, 447-70.

Metcalf, Lee Kendall (2000). "Measuring Presidential Power", Comparative Political Studies, 33:5, 660-85.

Morelli, Massimo (1999). "Demand Competition and Policy Compromise in Legislative Bargaining", American Political Science Review, 93:4, 809-20.

Protsyk, Oleh (2005). "Prime ministers' identity in semi-presidential regimes: Constitutional norms and cabinet formation outcomes", European Journal of Political Research, 44, 721-48.

Protsyk, Oleh (2006). "Intra-Executive Competition between President and Prime Minister: Patterns of Institutional Conflict and Cooperation under SemiPresidentialism.", Political Studies, 54, 219-44.

Rasch, Bjorn Erik, Shane Martin, and José Antonio Cheibub, eds. (2015). Parliaments and Government Formation: Unpacking Investiture Rules. Oxford: Oxford University Press.

Romer, Thomas, and Howard Rosenthal (1978). "Political Resource Allocation, Controlled Agendas, and the Status Quo", Public Choice, 33:4, 27-43.

Schleiter, Petra, and Edward Morgan-Jones (2009). "Party government in Europe? Parliamentary and semi-presidential democracies compared", European Journal of Political Research, 48:5, 665-93.

Schleiter, Petra, and Edward Morgan-Jones (2010). "Who's in Charge? Presidents, Assemblies, and the Political Control of Semipresidential Cabinets", Comparative 
Political Studies, 43:11, 1415-41.

Shugart, Matthew Søberg (2005). "Semi-Presidential Systems: Dual Executive And Mixed Authority Patterns", French Politics, 3:3, 323-51.

Shugart, Matthew Søberg, and John M. Carey (1992). Presidents and Assemblies: Constitutional Design and Electoral Dynamics. Cambridge, New York: Cambridge University Press.

Siaroff, Alan (2003). "Comparative presidencies: The inadequacy of the presidential, semi-presidential and parliamentary distinction", European Journal of Political Research, 42:3, 287-312.

Strøm, Kaare, Ian Budge, and Michael Laver (1994). "Constraints on cabinet formation in parliamentary democracies", American Journal of Political Science, 38:2, 303-35.

Ward, Michael D., Brian D. Greenhill, and Kristin M. Bakke (2010). "The perils of policy by p-value: Predicting civil conflicts", Journal of Peace Research, 47:4, 36375.

Zarate's Political Collections (2015). World Political Leaders, 1945-2015. http://zarate.eu/countries.htm. 